Yüzüncü Yil Üniversitesi
Tarim Bilimleri Dergisi

Araştırma Makalesi (Research Article)

\title{
İleri Pamuk (G. hirsutum L.) Hatlarının Biplot Analiz Yöntemi ile Değerlendirilmesi
}

\section{Ramazan MIZRAK ${ }^{1}$, Remzi EKİNCí ${ }^{* 2}$, Sema BAŞBAĞ $\breve{G}^{3}$}

${ }^{1}$ Dicle Üniversitesi, Fen Bilimleri Enstitüsü, 21110, Diyarbakır, Türkiye

${ }^{2,3}$ Dicle Üniversitesi, Ziraat Fakültesi, Tarla Bitkileri Bölümü, 21110, Diyarbakır, Türkiye

${ }^{1}$ https://orcid.org/0000-0002-9481-2450 2https://orcid.org/ 0000-0003-4165-6631 3https://orcid.org/0000-0002-9324-5175

*Sorumlu yazar e-posta: remzi.ekinci@dicle.edu.tr

\section{Makale Bilgileri}

Geliş: 04.03.2020

Kabul: 10.07.2020

Online Yayınlanma 31.12.2020

DOI: 10.29133/yyutbd.698594

\section{Anahtar kelimeler}

Bismil,

Biplot,

Diyarbakır,

Hat,

Pamuk.
Öz: Bu çalışma, Diyarbakır ili Merkez ve Bismil ilçeleri ekolojik koşullarında pamuk bitkisinin bazı verim ve lif kalite özellikleri arasındaki ilişkileri belirlemek amacıyla yürütülmüştür. Çalışma, 2018 yılında 9 adet pamuk çeşit adayı olan 1slah hatları (Aday 1-9) ve 3 adet standart pamuk çeşidi (ST-468, BA-119 ve DP396) materyal olarak kullanılarak, tesadüf blokları deneme desenine göre 3 tekerrürlü yürütülmüştür. Çalışmada tek koza kütlü ağırlı̆ğ (gr), pamuk kütlü verimi (kg/da), 100 tohum ağırlığı (gr), çıç̧ır randımanı (\%), lif uzunluğu (mm), lif inceliği (mic.), lif kopma dayanıklılığı (gr/tex), iplik olabilirlik indeksi özellikleri irdelenmiştir. İncelenen özellikler arası ikili ilişkiler ile biplot analizleri yapılmıştır. Tüm özellikler dikkate alındı̆̆ında Diyarbakır Merkez ekolojik lokasyonu için Aday-9, Aday-7, Aday-3, Aday-1, ST-468 ve Aday-2 genotiplerinin uygun olduğu; Bismil lokasyonu için sadece Aday-8 genotipinin uygun olduğu ve tavsiye edilebileceği; Aday-8 genotipinin ise en düşük stabiliteye sahip olduğu saptanmıştır. Yeni pamuk çeşit adaylarının farklı ve fazla lokasyon koşullarındaki performanslarının ve genotip x lokasyon ilişkisinin irdelenmesinde biplot analizlerinin oldukça isabetli olabileceği sonucuna varılmıştır.

\section{Evaluation of Advanced Cotton (G. hirsutum L.) Lines By Biplot Analysis Method}

\section{Article Info}

Received: 04.03.2020

Accepted: 10.07.2020

Online Published 31.12.2020

DOI: 10.29133/yyutbd.698594

\section{Keywords}

Bismil,

Biplot,

Diyarbakır,

Line,

Cotton.

\begin{abstract}
This study was carried out in randomized block design with 3 replications 9 cotton lines (Line 1-9) and 3 standard cotton varieties (ST4-68, BA119, and DP-396) were used as material in Diyarbakır Central and Bismil ecological conditions in 2018. There were examined single boll weight (g), cotton seed yield $\left(\mathrm{kg} \mathrm{da}^{-1}\right), 100$ seed weight $(\mathrm{g})$, gin output (\%), fiber length (mm), fiber fineness (mic.), fiber strength ( $\mathrm{gr} \mathrm{tex}^{-1}$ ), spinning consistency index in this study. Inter-feature correlation analysis and biplot analyzes were performed for the examined. Considering all investigated traits, Line-9, Line-7, Line-3, Line-1, ST468 and Line-2 genotypes were suitable and satisfactory for the ecological location of Diyarbakır. However, only the Line-8 genotype is recommended for the Bismil location as it is a suitable and satisfactory genotype. Line-8 genotype stability was determined as the lowest genotype. It was concluded that biplot analysis produced very good information in examining the genotype $\mathrm{x}$ location relationship and the performance of new lines in different and more location conditions.
\end{abstract}




\section{Giriş}

Pamuk (G. hirsutum L.), birçok ülkede olduğu gibi ülkemizde de yarattı̆̆ katma değer, oluşturduğu istihdam ve birçok sektörün hammadde kaynağı olarak, dünya tarımsal üretim ve ticaretinde çok önemli stratejik konuma sahiptir. Gün geçtikçe dünya nüfusunun artmasının yanında sanayileşen ve kalkınan toplumlarda yaşam konforunun yükselmesi, pamuk lifinin tüketim ve ihtiyacını artırmıştır. Tüketilen lifler içerisinde yapay liflerin daha yüksek bir orana sahip olmasına karşın, insanların doğal liflere olan ilgilerinin artması ve sun'i sentetik liflere doğal liflerde bulunan birçok özelliğin kazandırılamaması nedeniyle pamuk, gün geçtikçe daha cazip hale gelmektedir.

Uluslararası Pamuk İstişare Komitesi (ICAC, 2018) verilerine göre; pamuk ekim alanı açısından ülkeler sıralamasında, Türkiye 2013-2014 yılları arasında 10. Sıralarda iken; 2016-2017 yılları arasında 9. sıraya yükselmiştir. Dünyada toplam pamuk ekim alanı 2016-2017 yılları arasında 29.6 milyon hektar iken Türkiye, 530 bin hektar alana sahip olmuştur. Türkiye'de ekim alanı bakımında son yıllarda dalgalanmalar meydana gelmiştir. Bu dalgalanma teşviklerin yanında iklimsel değişikliklerden de kaynaklanmaktadır. 2017-2018 yıllarında ise Türkiye'de düşüş meydana gelmiştir. Dünya lif pamuk verim değerleri incelendiğinde, 2017-2018 sezonunda, Dünya ortalaması dekara 77 kg iken, Türkiye dekara $182 \mathrm{~kg}$ ile 3. sırada yer almıştır (ICAC, 2018; Özüdoğru, 2018).

Ülke ekonomisinde önemli bir yer tutan pamuğun, verimliliği açısından da ıslah çalışmaları yapılarak pamuk lif kalite özellikleri üstün çeşitlerin üretime alınması büyük önem arz etmektedir (Gençer ve Yelin, 1983). Yeni geliştirilmiş pamuk genotiplerinin farklı çevrelerde veya farklı yıllarda denemelerinin kurulması ile genotipin farklı çevre koşullarına olan tepkilerinin bilinmesi, pamuk yetiştiriciliği ve hatta pamuk ile ilgili incelenen özellikler yönünden büyük önem taşımaktadır.

Genotip ve çevre ilişkileri birçok bilimsel tez ve proje çalışmalarına konu olmuştur. $\mathrm{Bu}$ çalışmalarda elde edilen sonuçlar, oluşturulan genotip grupları veya oluşturulan çevre grupları içerisinde herhangi bir tanesinin değişmesi durumunda geçerliliğini yitirmektedir. Bu nedenle seçilerek oluşturulan genotip ve çevre gruplarının, çok iyi seçilmesi verimlilikte başarıyı artıracaktır.

Bu çalışma, Güneydoğu Anadolu bölgesi içerisinde pamuk üretim yönünden büyük öneme sahip Diyarbakır Merkez ve Bismil ilçe ekolojik koşullarında pamuk lif kalite parametrelerini incelemek, yeni geliştirilmiş pamuk hatlarının bu çevre koşullarındaki performanslarını ortaya koymak ve ileride bu konuda yapılacak çalışmalara yardımcı olmak amacı ile yürütülmüştür.

\section{Materyal ve Yöntem}

Diyarbakır ekolojik koşullarında, G. hirsutum L. türüne ait 9 adet ileri pamuk hattı ile ST-468, DP-396 ve BA-119 çeşitleri, denemede materyal olarak kullanılmıştır. Deneme, 3 tekerrürlü olarak tesadüf blokları deneme deseninde kurulmuştur. Deneme parseli $12 \mathrm{~m}$ uzunlukta ve 4 siralı olarak yapılandırılmıştır.

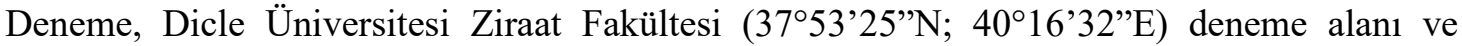
Diyarbakır ili Bismil ilçesi Tepe beldesinde (3747’29’N; 4046’48”E) çiftçi koşullarında 2018 yılında yürütülmüştür. 2018 yılı denemenin yürütüldügü lokasyonlara ait minimum, maksimum ve ortalama sıcaklık değişimleri, Şekil 1'de; nispi nem değişimleri ise Şekil 2'de verilmiştir.

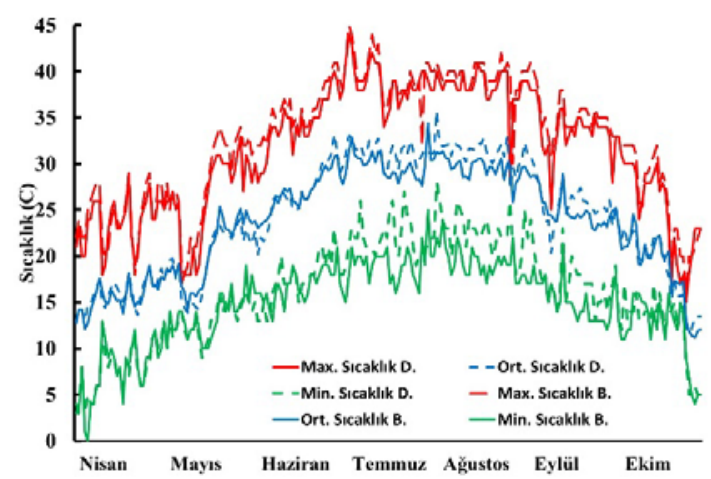

Şekil 1. 2018 Y1lı Nisan-Ekim Dönemi Diyarbakır ve Bismil Lokasyonların Sıcaklık Değişimleri $\left({ }^{\circ} \mathrm{C}\right)$.

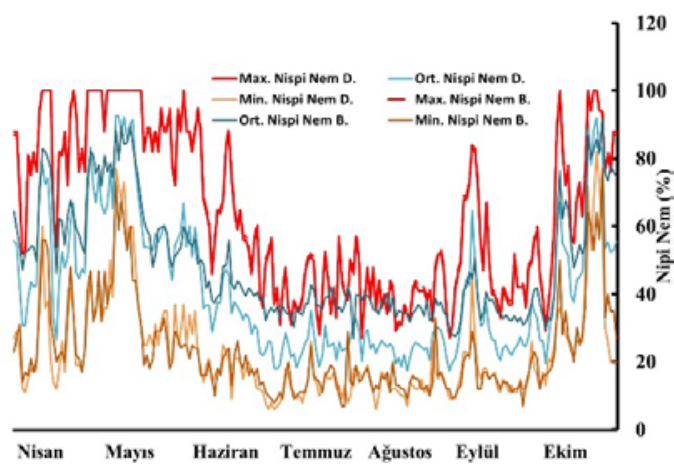

Şekil 2. 2018 Yılı Nisan-Ekim Dönemi Diyarbakır ve Bismil Lokasyonların Nispi Nem Değişimleri (\%). 
İklim özelliklerine baktığımızda pamuk için ekim döneminde istenilen $15^{\circ} \mathrm{C}$ ve üzeri sıcaklık Nisan-Mayıs aylarında yakalanmış, yetişme süreci boyunca sıcaklık değerlerinin $20^{\circ} \mathrm{C}$ üzeri olması ve yaz aylarında $25^{\circ} \mathrm{C}$ civarlarındaki seyretmesi, taraklanmayı olumlu yönde etkilemiştir (Şekil 1 ve Şekil 2). Dicle Üniversitesi ve Diyarbakır/Bismil ilçesi uygulama alanı deneme yeri itibariyle toprakları düz ya da düze yakın eğimlerde, derin ya da orta derin, $\mathrm{ABC}$ profilli zonal topraklardır. Toprak yapısı bakımından ana maddesi ince bünyeli alüvyal materyal ya da kireç tasından ibaret olup pH derecesi 7.75-7.85 aralığındadır.

Ekim, 20 Nisan tarihinde deneme mibzeri ile yapılmıştır. Gerçek yaprakların çıkışından sonra seyreltme işlemi yapılmıştır. Ekim öncesi toprak hazırlığında taban gübresi olarak kompoze gübre (20.20.0) formunda $40 \mathrm{~kg} / \mathrm{da}$, üst gübre olarak üre formunda $20 \mathrm{~kg} / \mathrm{da}$ verilmiştir. Denemede, $8 \mathrm{kez} \mathrm{karık}$ usulü sulama yapılmıştır. Hasat elle 2 defada yapılmıştır. Çalışma kapsamında, tek koza kütlü ağırlığı (gr)(TKKA), pamuk kütlü verimi (kg/da)(PKV), 100 tohum ağırlı̆̆ (gr)(100TA), çırçır randımanı (\%) (ÇR), lif uzunluğu (mm) (LU), lif inceliği (mic.) (Lİ), lif kopma dayanıklılığı (gr/tex) (LKD), iplik olabilirlik indeksi (İOI) özellikleri incelenmiştir.

Çalışma kapsamında incelenen özellik arası ikili ilişkiler, JMP 5.0 (Copyright (C) 1989 - 2002 SAS Institute Inc.) istatistik paket programı ile analiz edilmiştir. GGE Biplot analizleri, Yan (2002) ile Yan ve Kang (2002)'ın belirttikleri yöntemler esas alınarak gerçekleştirilmiş, grafiklerdeki önemlilik dereceleri ise vektör grafiklerindeki vektörler arası açılar dikkate alınarak belirlenmiştir (Yan, 2002). Çalışma, GGE Biplot analiz grafikleri Genstat $14^{\text {th }}$ paket programı kullanılarak yapılmıştır.

\section{Bulgular ve Tartışma}

Tüm materyalleri içerecek şekilde incelenen özellikler arası ikili ilişkiler (korelasyon analizi) analiz sonuçları Çizelge 1'de verilmiştir.

Çizelge 1. İncelenen özellikler arası ikili ilişkiler (korelasyon analizi) analiz sonuçları

\begin{tabular}{|c|c|c|c|c|c|c|c|}
\hline & TKKA & PKV & $100 \mathrm{TA}$ & CR & $\mathrm{LI}$ & İOİ & $\mathrm{LU}$ \\
\hline PKV & $-0.45^{* *}$ & & & & & & \\
\hline 100 TA & $0.61 * *$ & -0.12öd & & & & & \\
\hline ÇR & $-0.59 * *$ & $0.36 * *$ & $-0.71^{* *}$ & & & & \\
\hline LI & -0.23öd & 0.22öd & -0.09öd & 0.19öd & & & \\
\hline İOİ & $0.62 * *$ & $-0.63 * *$ & $0.40^{* *}$ & $-0.62 * *$ & $-0.53 * *$ & & \\
\hline LU & $0.70 * *$ & $-0.68 * *$ & $0.42 * *$ & $-0.62 * *$ & $-0.30 *$ & $0.85^{* *}$ & \\
\hline LKD & $0.66^{* *}$ & $-0.63 * *$ & $0.38 * *$ & $-0.54 * *$ & $-0.33 * *$ & $0.91^{* *}$ & $0.76 * *$ \\
\hline
\end{tabular}

PKV: Pamuk kütlü verimi, 100 TA: 100 tohum ağırlığı, ÇR: Çırçır randımanı, TKKA: Tek koza pamuk kütlü ağırlığı, , LU: Lif uzunluğu, Lİ: Lif inceliği, LKD: Lif kopma dayanıklılığı, İȮ̇: İplik olabilirlik indeksi

Çizelge 1’de, pamuk kütlü verimi ile tek koza kütlü ağırlığ $\left(\mathrm{r}=-0.45^{* *}\right), 100$ tohum ağırlığı $(\mathrm{r}=-$ $\left.0.12^{\text {od }}\right)$ iplik olabilirlik indeksi ( $\left.\mathrm{r}=-0.63^{* *}\right)$, lif uzunluğu $\left(\mathrm{r}=-0.68^{* *}\right)$ ve lif kopma dayanıkl11 $\breve{g} 1(\mathrm{r}=-$ $\left.0.63^{* *}\right)$ özellikleri arasında olumsuz; çırçır randımanı $\left(\mathrm{r}=+0.36^{* *}\right)$ ve lif incelik ( $\mathrm{r}=+0.22$ öd) özellikleri arasında olumlu ikili ilişkiler saptanmıştır.

100 tohum ağırlığı ile çırçır randımanı ( $\left.\mathrm{r}=-0.71^{* *}\right)$, lif inceliği $(\mathrm{r}=-0.090 ̈ \mathrm{~d})$ pamuk kütlü verimi $\left(\mathrm{r}=-0.12^{* *}\right)$ özellikleri arasında olumsuz; iplik olabilirlik indeksi $\left(\mathrm{r}=+0.40^{* *}\right)$, lif kopma dayanıklılığ $\left(\mathrm{r}=+0.38^{* *}\right)$, lif uzunluğu $\left(\mathrm{r}=+0.42^{* *}\right)$ ve tek koza kütlü pamuk ağırlığı $(\mathrm{r}=+0.61 * *)$ özellikleri arasında olumlu ikili ilişkiler belirlenmiştir.

Çırçır randımanı ile 100 tohum ağırlığ $\left(\mathrm{r}=-0.71^{* *}\right)$, tek koza kütlü pamuk ağırlığ $\left(\mathrm{r}=-0.59^{* *}\right)$, iplik olabilirlik indeksi özelliği $\left(\mathrm{r}=-0.62^{* *}\right)$, lif kopma dayanıklılı̆̆ $1\left(\mathrm{r}=-0.54^{* *}\right)$, lif uzunluğu $(\mathrm{r}=-$ $\left.0.62^{* *}\right)$ özellikleri arasında olumsuz; lif inceliği ( $\mathrm{r}=+0.19$ öd $)$ ve pamuk kütlü verimi $\left(\mathrm{r}=+0.36^{* *}\right)$ özellikleri arasında olumlu ikili ilişkiler saptanmıştır.

Lif inceliği ile tek koza kütlü pamuk ağırlığ ( $\mathrm{r}=-0.23$ öd), 100 tohum ağırlığı (r=-0.09öd) iplik olabilirlik indeksi ( $\left.\mathrm{r}=-0.53^{* *}\right)$, lif kopma dayanıklılığ $\left(\mathrm{r}=-0.33^{* *}\right)$, lif uzunluğu $\left(\mathrm{r}=-0.30^{*}\right)$ özellikleri arasında olumsuz; pamuk kütlü verimi ( $\mathrm{r}=+0.22$ öd) ve çırçır randımanı ( $\mathrm{r}=+0.19$ öd) özellikleri arasında olumlu ikili ilişsiler belirlenmiştir.

İplik olabilirlik indeksi ile pamuk kütlü verimi arasında $\left(\mathrm{r}=-0.63^{* *}\right)$, çırçır randımanı $(\mathrm{r}=-$ $\left.0.62^{* *}\right)$ ile lif inceliği $\left(\mathrm{r}=-0.53^{* *}\right)$ arasında olumsuz; 100 tohum ağırlığ $\left(\mathrm{r}=+0.40^{* *}\right)$ ile lif kopma 
dayanıklılığı $\left(\mathrm{r}=+0.91^{* *}\right)$, lif uzunluğu $\left(\mathrm{r}=+0.85^{* *}\right)$ ve tek koza kütlü pamuk ağırlığı $(\mathrm{r}=+0.62 * *)$ arasında olumlu ikili ilişkiler belirlenmiştir.

Lif uzunluğu ile pamuk kütlü verimi ( $\left.\mathrm{r}=-0.68^{* *}\right)$, çırçır randımanı $\left(\mathrm{r}=-0.62^{* *}\right)$, lif inceliği $(\mathrm{r}=-$ $\left.0.30^{*}\right)$ arasında olumsuz; 100 tohum ağırlığ $\left(\mathrm{r}=+0.42^{* *}\right)$, lif kopma dayanıklılı $\mathrm{g} 1\left(\mathrm{r}=+0.76^{* *}\right)$, tek koza kütlü pamuk ağırlığı $\left(\mathrm{r}=+0.70^{* *}\right)$ ve iplik olabilirlik indeksi $\left(\mathrm{r}=+0.85^{* *}\right)$ özellikleri arasında olumlu ikili ilişkiler saptanmıştır.

Lif kopma dayanıklılı̆g 1 ile pamuk kütlü verimi ( $\left.\mathrm{r}=-0.63^{* *}\right)$, çıç̧ır randımanı ( $\left.\mathrm{r}=-0.54^{* *}\right)$, lif inceliği $\left(\mathrm{r}=-0.33^{* *}\right)$ özellikleri arasında olumsuz; 100 tohum ağırlığı $\left(\mathrm{r}=+0.38^{* *}\right)$, lif uzunluğu $\left(\mathrm{r}=+0.76^{* *}\right)$, tek koza kütlü pamuk ağırlığı $\left(\mathrm{r}=+0.66^{* *}\right)$ ve iplik olabilirlik indeksi $\left(\mathrm{r}=+0.91^{* *}\right)$ özellikleri arasında olumlu ikili ilişkiler belirlenmiştir.

Elde ettiğimiz bulgular ile lif uzunluğu özelliği ile çırçır randımanı, lif verimi ve pamuk kütlü verimi özellikleri arasında negatif korelasyon saptandığını belirten Başbağ ve ark., (2008), Karademir ve ark., (2009), Güvercin ve Sunulu (2010) bulguları benzerlik göstermektedir.

İncelenen özelliklerin ortalama değerleri üzerinden yapılan biplot analizlerde GenotipLokasyon analiz sonuçları Şekil 3'de verilmiştir. Toplam varyasyon içinde \%54 ile PC1'in PC2'den daha yüksek varyasyona sahip olduğu, PC1 ve PC2'nin toplamının ise bir varyasyon teşkil ettiği görülmektedir. Tüm özellikler bakımından Aday-8 genotipi, Bismil lokasyonunda en iyi genotip konumunda iken, Aday-9 genotipi Bismil lokasyonu için en kötü genotip olarak; Aday-9 genotipi Diyarbakır Merkez lokasyonunda en iyi genotip; Aday-8 genotipi ise Diyarbakır Merkez lokasyonu için en kötü genotip olarak belirlenmiştir. Tüm özellikler dikkate alındığında merkeze (orijin noktası) yaklaştıkça genotiplerin her iki lokasyon için uygunluğu artar. Diyarbakır lokasyonu için Aday-9, Aday7, Aday-3, Aday-1, ST-468 ve Aday-2 genotiplerinin uygun genotipler olduğu; merkeze yakın yer alan BA-119 ve DP-396 genotiplerinin ise her iki lokasyon için uygun genotipler olduğu, ancak çok yeterli olmadığı saptanmıştır. Bunun aksine Aday-4, Aday-5 ve Aday-6 genotiplerinin her iki (Bismil ve Diyarbakır) lokasyon için çok iyi olmadığı görülmektedir. Genotipler her iki lokasyona uygunluk olarak (Bismil ve Diyarbakır) dikkate alındığında çok iyi sonuçlar vermemiştir (Şekil 3).

Pamuk verim özelliklerinden pamuk kütlü verimi ile bazı lif kalite özelliklerinin birbiri ile olumsuz ikili ilişkiye sahip olması, incelenen pamuk kütlü verim ve lif kalite özelliklerinin, bir arada iyi olmasını engellemekte olduğu yargısını ortaya koymaktadır. Çizelge 1'deki sonuçlar bu yargısı desteklemektedir.

Diyarbakır Merkez ve Bismil lokasyonlarında Aday-8 genotipi en yüksek performansı göstermesine rağmen, stabilite değeri en düşük olan genotip konumunda olduğu; Aday-9, Aday-7, Aday-3 ve ST-468 genotiplerinin Aday-8 genotipini takip ettiği belirlenmiştir. Aday-9, Aday-7, Aday3 ve ST-468 genotiplerinin, Bismil lokasyonundan çok Diyarbakır Merkez lokasyonu için uygun olduğu görülmektedir. En stabil genotipin DP-396 olduğu, ancak Aday-1 genotipinin, ortalama değerlerin üzerinde ve stabil olduğu görülmektedir. Aday-8 genotipi ortalama değerlerin en üst değerine sahip ancak stabilite değerinin düşük olması, üretimde risk oluşturduğu ancak yüksek performans için yetiştirilebileceği tavsiye edilmektedir (Şekil 4).

Tüm özellikler dikkate alınarak yapılan analiz sonucunda 4 ana sektör yerine oluştuğu görülmektedir (Şekil 5.) Tüm özellikler dikkate alınarak Bismil ve Diyarbakır merkez lokasyonlarımızın farklı sektörlerde yer aldığ 1 görülmektedir. Bu durum, tüm özellikler dikkate alındığında ekolojik yapıları incelenen iki lokasyonun birbirinden farklı olduğunu göstermektedir. Diyarbakır Merkez lokasyonu ile birlikte Aday-1, Aday-2, Aday-3, Aday-7, Aday-9 ve ST-468 genotipleri aynı sektörde (1 nolu sektörde); Bismil lokasyonu ile birlikte sadece Aday- 8 genotipi aynı sektörde (2 nolu sektor) yer almış olduğu görülmektedir. Aday-5, Aday-4, Aday-6, BA-119 ve DP-396 genotipleri 3 nolu sektrörde yer almiş olup, hiçbir lokasyon ile ilişkilendirilememiştir. 4 nolu sektörde ise herhangi bir genotip yer almamış olup, en yakın genotip olarak 2 nolu genotip olduğu saptanmıştır. 1 nolu sektör bakımından Aday-9 genotipi, 2 nolu sektör bakımından Aday-8, 3 nolu sektör bakımından Aday-5 genotipi, en iyi genotip konumunda olduğu saptanmıştır (Şekil 5). Bu durum, Diyarbakır merkez ekolojik koşullarında Aday-9 ve Bismil ekolojik koşullarında ise Aday- 8 genotipleri en iyi performansı gösterdiğinden yetiştiriciliği tavsiye edilmektedir.

İncelenen özelliklere ilişkin tüm ortalama veriler üzerinden 1 adet ideal merkez oluşturulmuştur (Şekil 6.) Bu merkez, en iç çember olarak görülmektedir. Bu ideal merkeze en yakın olan Aday-8 ve daha sonra Aday-9 genotipleri en ideal genotipler olarak saptanmıştır. Ortalama çizgisinin üzerinde olan Aday-1, Aday-3, Aday-7, Aday-9, Aday-8 ve ST-468 genotipleri tercih edilmesi gereken genotipler 
olup, ortalama çizgisinin altında kalan Aday-5, Aday-4, Aday-6, BA-119, DP-396 ve Aday-2 genotipleri tercih edilmemesi gereken kötü değer/sonuçlara sahip genotipler olduğu saptanmıştır (Şekil 6). Bu neden ile incelenen tüm özellikler dikkate alındığında Aday-5, Aday-4, Aday-6, BA-119, DP-396 ve Aday-2 genotiplerin yetiştirilmemesi tavsiye edilmektedir.

İncelenen özelliklerin ortalaması üzerinden yapılan biplot analizlerden Genotip-Özellik analiz sonuçları Şekil 7'de verilmiştir. İki özellik arasındaki açı azaldıkça korelasyonun yüksek ve pozitif olduğu; açı değeri, 90 dereceye kadar ise pozitif korelasyonun olduğu; 90 dereceye eşit ise korelasyonun olmadığı; 90 dereceden fazla ise korelasyonun negatif olduğu; açı derecesi 180 dereceye yaklaştıkça korelasyonun yüksek ve negatif olduğunu gösterir. Bir özelliğin vektör uzunluğu arttıkça toplam özellikler içindeki etki payının arttığını, vektör uzunluğu azaldıkça özellikler içindeki etki payının düştüğünü göstermektedir. Hangi genotip hangi özellik vektörüne yakın ise o genotip, o özellik/özellikler yönünden, iyi olduğunu göstermektedir. Genotipler, merkezden (orijinden) dişa doğru açıldıkça ve özellik vektörüne (yakın olan) yaklaştıkça, söz konusu genotipin yakın olduğu özellikler bakımından oldukça yüksek değerlere sahip veya tatminkar olduğunu göstermektedir. Aday-8, Aday-9 ve Aday-7 genotipleri 100 tohum ağırlığı, lif kopma dayanıklılığı ve pamuk kütlü verimi özellikleri bakımından iyi olduğunu göstermektedir. DP-396, BA-119 ve ST-468 genotipleri, verim ve iplik olabilirlik indeksi özellikleri bakımından iyi sonuçlara sahip iken diğer özellikler bakımından geride olduğu görülmektedir. Aday-2, Aday-3, Aday-4 ve Aday-5 genotipleri çırçır randımanı, lif inceliği, tek koza ağırlığı ve lif uzunluğu özellikleri bakımından iyi sonuçlara sahip olduğunu ve diğer özellikler bakımından da kötü olduğunu göstermektedir. Bu durum, gelecekte yapılacak pamuk islah çalışmalarında lif kopma dayanıklılı̆̆ 1,100 tohum ağırlığı bakımından Aday-8 ve Aday-9 genotipleri, pamuk kütlü verim özelliği için Aday-7, ST-468 ve DP-396 genotipleri, lif uzunluğu, lif inceliği ve tek koza kütlü pamuk ağırlığı özellikleri bakımından ise Aday-2, Aday-3, Aday-4 ve Aday-5 genotiplerinin ebeveyn olarak kullanılması tavsiye edilmektedir (Şekil 7).

İleri genotiplerin lokasyon koşullarında performanslarının incelenmesi, genotip x lokasyon ilişkilerinin irdelenmesi yönünden biplot analizlerinin, oldukça açıklayıcı bilgi ürettiği saptanmıştır.

Elde ettiğimiz bulgular, biplot analizlerin genotip ve çevre interaksiyonları çalışmalarında detaylı ve açılayıcı olduğunu belirten Gül ve ark. (2014), Kendal ve Doğan, (2015), Ali ve ark. (2017), Akcura ve ark. (2017), Alp ve Kahraman (2017), Kendal ve ark. (2019), Oral ve ark. (2019) bulgularını destekler niteliktedir.

\section{Sonuç}

Gossypium hirsutum L. türüne ilişkin, 9 adet aday hat ile 3 adet standart pamuk çeşidinin materyal olarak kullanılarak Bismil ve Diyarbakır Merkez ekolojik lokasyonlarda yürütülen tek koza kütlü ağırlığı, pamuk kütlü verimi, çırçır randımanı, 100 tohum ağırlı̆̆ı, lif inceliği, lif uzunluğu, lif kopma dayanıklılığı ve iplik olabilirlik indeksi özelliklerinin incelendiği bu çalışmada, iki farklı lokasyonda genotiplerin performansları ve uyumları incelemiş; incelenen özellikler arasında oluşan ikili ilişkiler belirlenmiş ve biplot analizleri ile irdelenmiştir.

Yapılan çalışmadan, pamuk kütlü verimi ve 100 tohum ağırlığı özellikleri yönünden incelenen Bismil ve Diyarbakır merkez ekolojik lokasyonları arasında; pamuk genotipleri arasında ve lokasyon x genotipler interaksiyonu arasında farklılıkların istatistiki olarak önemli olduğu; incelenen verim ve lif kalite özelliklerinden tek koza pamuk kütlü ağırlığı ve çırçır randımanı ile lif uzunluğu, lif inceliği ve iplik olabilirlik indeksi özellikleri yönünden genotipler arasındaki farklılıkların istatistiki olarak önemli olduğu; tüm özellikler dikkate alındığında Diyarbakır Merkez ekolojik lokasyonu için Aday-9, Aday-7, Aday-3, Aday-1, ST468 ve Aday-2 genotipleri uygun ve tatminkâr; Bismil lokasyonu için sadece Aday8 genotipi uygun ve tatminkâr genotip olarak tavsiye edildiği; Aday- 8 genotipinin stabilitesi en düşük olduğu; bu genotipin genetik olarak değişen çevre koşullarından çok fazla etkilendiği ve bu yüzden yetiştirilebilir ancak risk faktörünün yüksek olduğu saptanmıştır. Yeni çeşit adaylarının farklı ve fazla lokasyon koşullarındaki performanslarının belirlenmesinde ve genotip x lokasyon ilişkisinin irdelenmesinde biplot analizlerinin isabetli bir yöntem olabileceği sonucuna varılmıştır. 


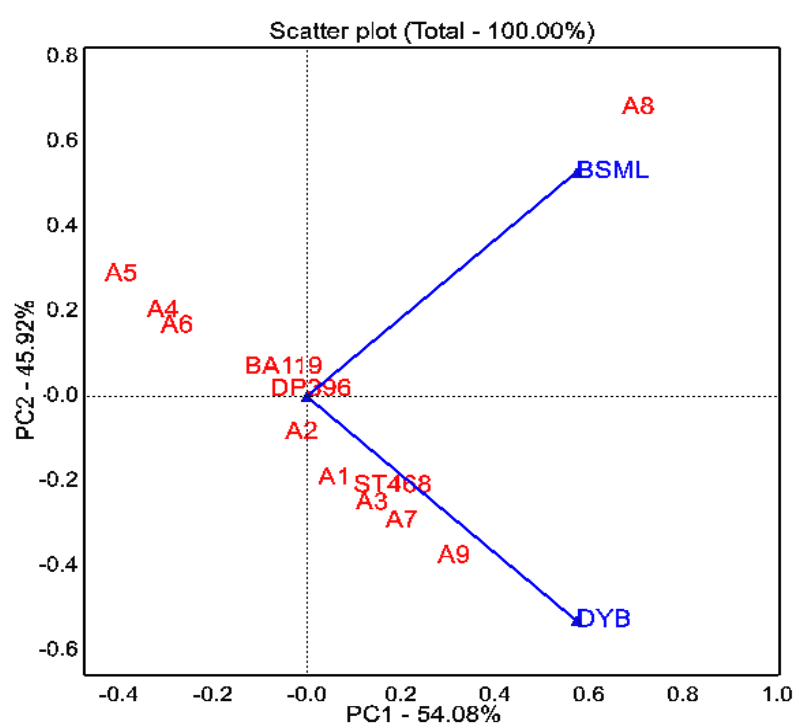

Şekil 3. Genotip-Lokasyon Biplot analiz sonuçları (Scatterplot).

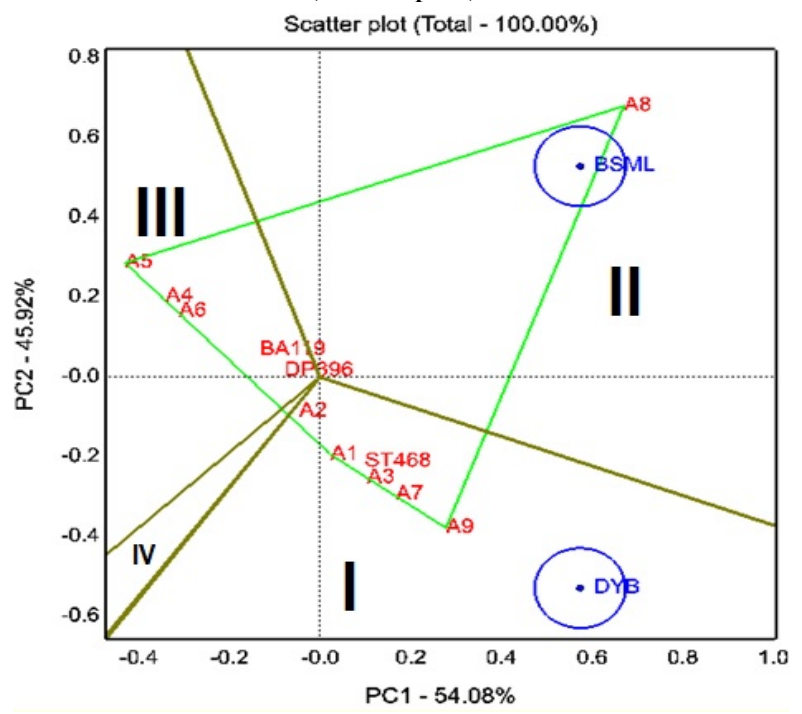

Şekil 5. Genotip-Lokasyon Biplot analiz sonuçları (Sector Plot-Mega Lokasyon). Scatter plot (Total - $60.00 \%$ )

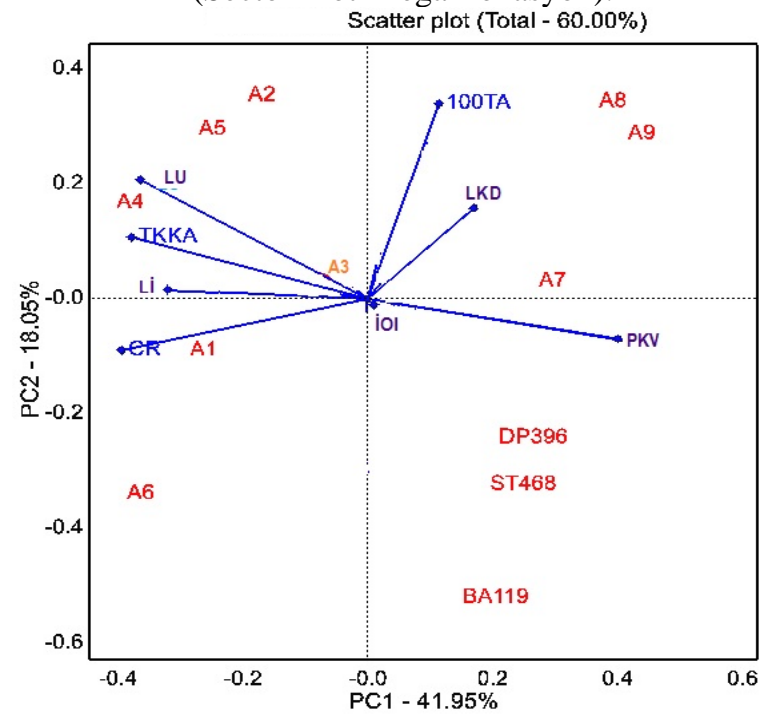

Şekil 7. Genotip-Özellik Biplot analiz sonuçları (Scatter Plot).

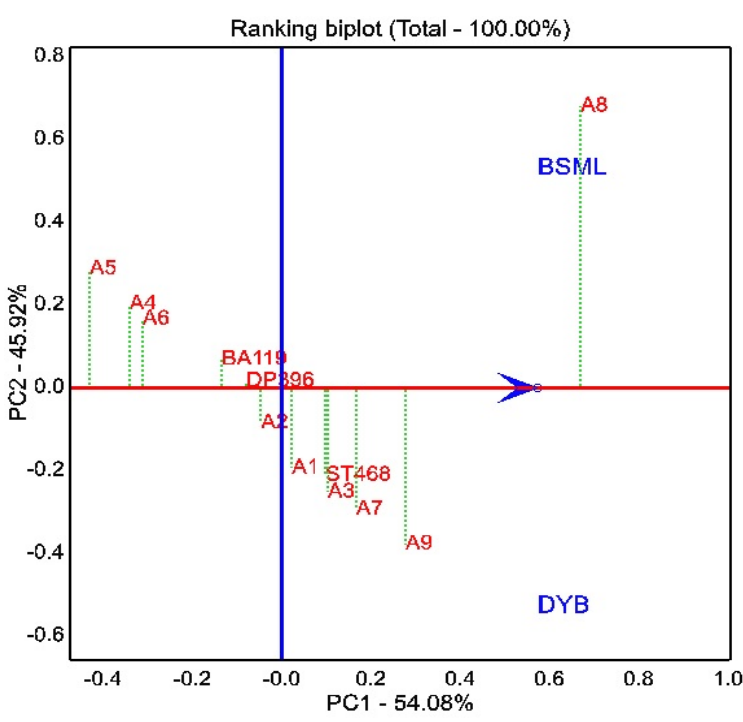

Şekil 4. Genotip-Lokasyon Biplot analiz sonuçları (Ranking Biplot).

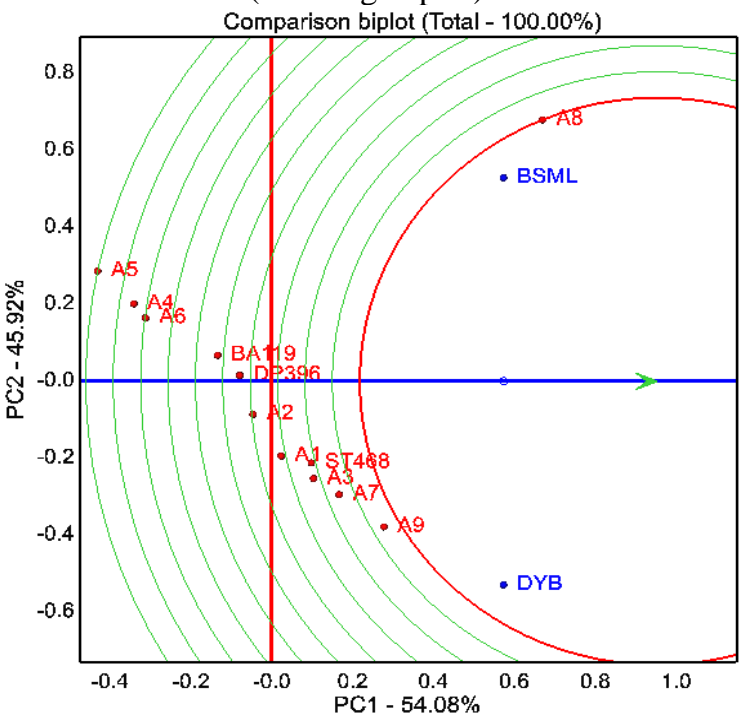

Şekil 6. Genotip-Lokasyon Biplot analiz sonuçları (Comparison Biplot).

Scatter plot (Total - $60.00 \%$ )

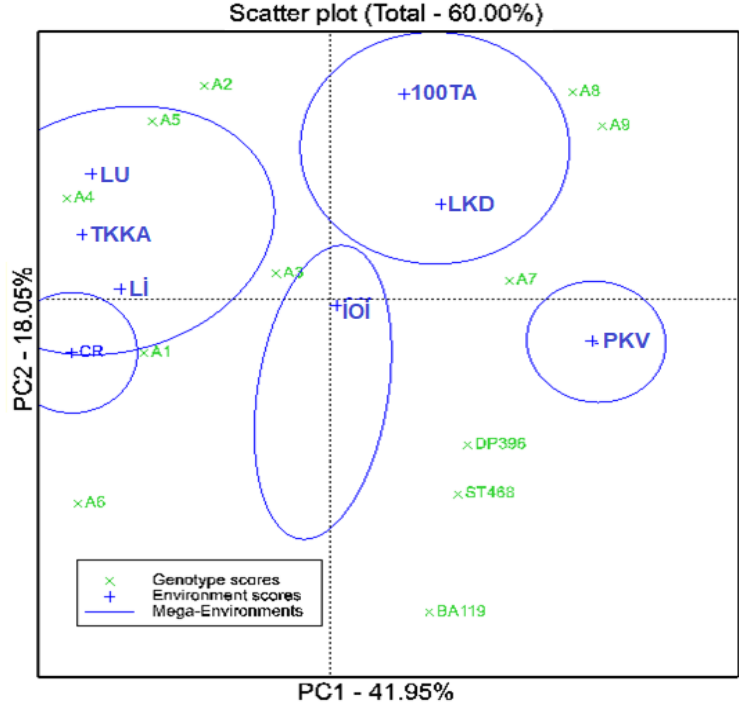

Şekil 8. Genotip-Özellik Biplot analiz sonuçları (Scatter Plot Grup). 


\section{Teşekkür}

Bu çalışma, Ramazan MIZRAK tarafindan Dicle Üniversitesi Fen Bilimleri Enstitüsü Tarla Bitkileri ana bilim dalında yürütülen "Diyarbakır ekolojik koşullarında pamuğun (Gossypium hirsutum L.) bazı genotiplerinin verim ve lif kalite özelliklerinin araştırılması" başlıklı yüksek lisans tezinden üretilmiş olup, Dicle Üniversitesi Bilimsel Araştırma Projeleri Koordinasyon Birimi tarafindan ZIRAAT.18.021 nolu proje numarası ile desteklenmiştir. Bilimsel Araştırma Koordinasyon Birimi'ne desteğinden ötürü teşekkür ederiz.

\section{Kaynakça}

Akcura, M., Akan, K., \& Hocaoglu, O. (2017). Biplot analysis of leaf rust resistance in pure lines selected from Eastern Anatolian bread wheat landraces of Turkey. Turkish Journal of Field Crops 22(2), 227-234.

Ali, I, Khan, N.U., Mohammad, F., Iqbal, M.A., Abbas, A., Farhatullah, Bibi, Z., Ali, S., \& Khalil, I.A. (2017). Genotype by environment and GGE-Biplot analyses for seed cotton yield in upland cotton, Pak. J. Bot., 49(6), 2273-2283, 2017.

Alp, A., \& Kahraman, Ş. (2017). Diyarbakır koşullarında ana ve ikinci ürün olarak yetiştirilen tane mısırın bazı tarımsal ve teknolojik özelliklerinin biplot analiz yöntemiyle karşılaştırılması. Yüzüncü Yıl Üniversitesi Tarım Bilimleri Dergisi, 27 (4), 507-515. DOI: 10.29133/yyutbd.299291

Başbağ, S., Ekinci, R., \& Gençer, O. (2008). Pamukta bazı karakterlere ilişkin heterotik etkiler ve korelasyon analizleri, Tartm Bilimleri Dergisi (Journal of Agricultural Sciences), 14 (2), 143147.

Gençer, O. \& Yelin, D., (1983). Pamuk Bitkisinde (Gossypium hirsutum L.) Erkencilik Kriterlerinin Kalıtımı ve Verimle İlişkileri Üzerine bir Araştırma. Bölge Pamuk Araştırma Enstitüsü Müdürlüğü. Adana. Yayın No: 40.

Gul, S., Khan, N.U., Batool, S., Baloch, M.J., Munir, M., Sajid, M., Khakwani, A.A., Ghaloo, S.H., Soomro, Z.A., \& Kazmi, S.F. (2017). Genotype by environment interaction and association of morpho- yield variables in upland cotton. The Journal of Animal \& Plant Sciences, 24(1), 2014, Page: 262-271 ISSN, 1018-7081.

Güvercin, R.Ş. \& Sunulu, S. (2010). Bazı Pamuk (Gossypium hirsutum L.x Gossypium barbadense L.) Melezlerinin Lif Özelliklerinde Heterosis ve Korelasyon Katsayıları. YYÜ TAR BIL DERG (YYU J AGR SCI), 2010, 20(2), 68-74.

ICAC, (2018). Cotton This Month, November 1, 2018

Karademir, E., Karademir, Ç., \& Ekinci, R. (2009). Uzun lifli ileri pamuk hatlarında verim ve lif teknolojik özelliklerde korelasyon analizleri. Türkiye VIII. Tarla bitkileri Kongresi, 19-22 Ekim 2009, HATAY

Kendal, E., Karaman, M., Tekdal, S., \& Doğan, S. (2019). Analysis of promısing barley (Hordeum vulgare L.) lines performance by AMMI and GGE biplot in multiple traits and environment. Applied Ecology and Environmental Research 17(2), 5219-5233.

Kendal, E., \& Doğan, Y. (2015). Stability of a candidate and cultivars (Hordeum vulgare L.) by GGE Biplot analysis of multi-environment yield trial in spring barley. Agriculture \& Forestry, Vol. 61, Issue 4, 307-318, 2015, Podgorica.

Oral, E., Kendal, H., Kılıç, H. \& Doğan, Y. (2019). Evolotion barley genotypes in multi-environment trials by AMMI model and GGE biplot analysis. Fresenius Environmental Bulletin, Volume 28 - No. 4A/2019 pages 3186-3196

Özüdoğru, T. (2018). Durum ve Tahmin PAMUK, Tarımsal Ekonomi ve Politika Geliştirme Enstitüsü, TEPGE YAYIN NO: 285, ISBN: 978-605-9175-89-0

Yan W. \& Kang M. S. (2002). GGE Biplot Analysis: A graphical tool for breeders, geneticists, and agronomists. CRC Press, Boca Raton, FL, pp.288.

Yan W. (2002). Singular-value partitioning for biplot analysis of multienvironment trial data. Agron J 94, 990-996. 